\title{
Investigating the role of commercialization on purchase intention
}

\author{
Naser Azad*, Maryam Safaee and Mahdieh Shahrabi Farahani
}

Department of Management and Accounting, South Branch, Islamic Azad University, Tehran, Iran

\begin{tabular}{l}
\hline C H R O N I C L E \\
\hline Article history: \\
Received December 28, 2013 \\
Received in revised format April \\
152014 \\
Accepted April 302014 \\
Available online \\
May 2 2014 \\
\hline Keywords: \\
Commercialization \\
Purchase intention \\
Factor analysis
\end{tabular}
\begin{abstract}
A B S T R A C T
This paper presents a study to determine the role of commercialization on purchase intention in auto industry. The study designs a questionnaire in Likert scale and distributes it among some randomly selected people who lived in city of Tehran, Iran. The study investigates the effects of four factors including competitive condition, product development strategy, competitive advantage and economic growth on customers' intention to purchase. Using structural equation modeling the study has determined a positive and meaningful relationship between each four components and purchase intention. In our study, the highest impact belongs to competitive condition followed by product development strategy.
\end{abstract}

(C) 2014 Growing Science Ltd. All rights reserved.

\section{Introduction}

During the past few years, there have been many studies associated with commercialization of products and services around the world (Schmidt-Mohr \& Villas-Boas, 2008). Ardichvili et al. (2003) constructed on existing theoretical and empirical investigations in the area of entrepreneurial opportunity identification and development. It utilizes Dubin's theory (1969) building framework to develop a theory of the opportunity identification process. It detected entrepreneur's personality traits, social networks, and prior knowledge as antecedents of entrepreneurial alertness to business opportunities. Bagchi-Sen (2007) studied the relative importance of alliances as an innovation strategy utilized by US biotechnology companies. According to Bandarian (2007), commercial potential is the opportunity of commercialization of the candidate technology.

According to Barney (1991), understanding origins of sustained competitive advantage plays essential role in strategic management. Barney (1991) examined the link between company resources and sustained competitive advantage by constructing on the assumptions that strategic resources were heterogeneously distributed across business units and that these differences become stable over time.

\footnotetext{
*Corresponding author.

E-mail addresses: n_azad@azad.ac.ir (N. Azad) 
Boehm and Hogan (2013) extended industrial marketing's B-2-B model by looking at public sector participants in collaborations in order to study the process of building scientific-knowledgecommercialization collaborations. They reported that retention was a catalyst for improving established collaborations to facilitate the commercialization of scientific knowledge through repeated projects. Collaborators become loyal and committed because they are in agreement with the overall relationship, commercialization service as well as quality. It is basic role that all collaborators understand each other's roles and motive as incongruities hamper the development of productive collaborations. Besides, universities require to develop a bigger appreciation of the role of satisfaction. Overall, the study explained the importance of repeat collaborations and the development of mutual advantages, which facilitate scientific knowledge commercialization. The study also showed how contextual differences influence on scientific knowledge commercialization in both Ireland and Germany.

\section{The proposed study}

The proposed study of this paper investigates the role of commercialization on purchase intention through the following study,

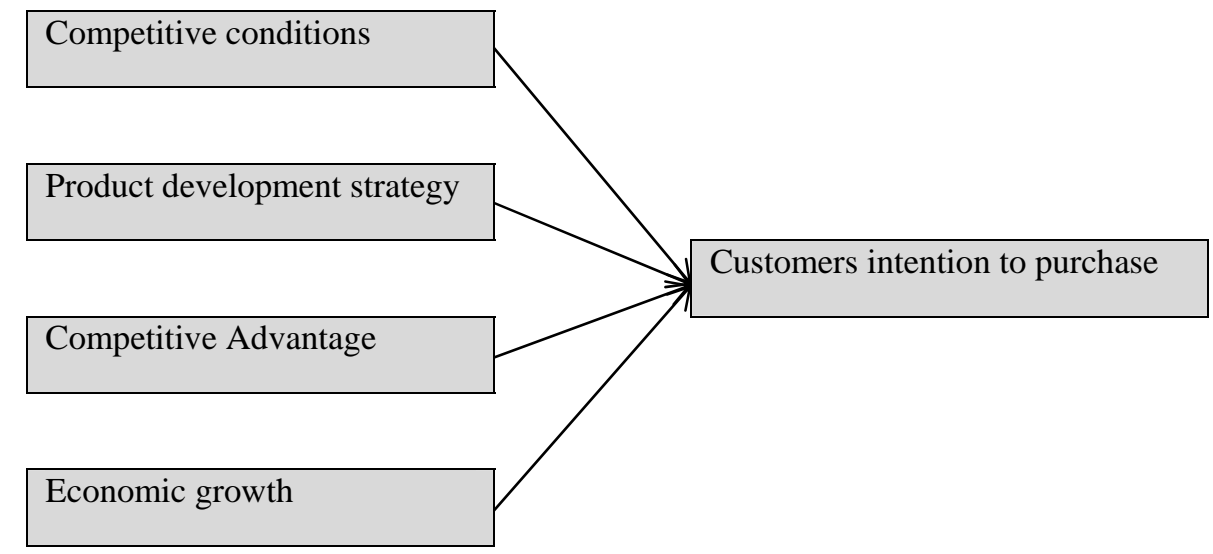

Fig. 1. The proposed study

As we can observe from Fig. 1, the study investigates the effects of four factors including competitive condition, product development strategy, competitive advantage and economic growth on customers' intention to purchase. The proposed study has been applied on regular customers in auto industry in city of Tehran, Iran. The sample size is calculated as follows,

$N=Z_{\alpha / 2}^{2} \frac{p \times q}{e^{2}}$,

where $N$ is the sample size, $p=1-q$ represents the probability, $z_{\alpha / 2}$ is CDF of normal distribution and finally $\varepsilon$ is the error term. For our study we assume $p=0.5, z_{\alpha / 2}=1.96$ and $e=0.05$, the number of sample size is calculated as $N=230$. The study has designed a questionnaire and distributed it among some randomly selected people. Cronbach alpha has been calculated as 0.833 , which is well above the minimum acceptable level. In our survey, $67 \%$ of the participants were male and $33 \%$ of them were female and over $81 \%$ of them had, at least, 5 years of job experiences. Fig 2 shows other characteristics of the participants. 


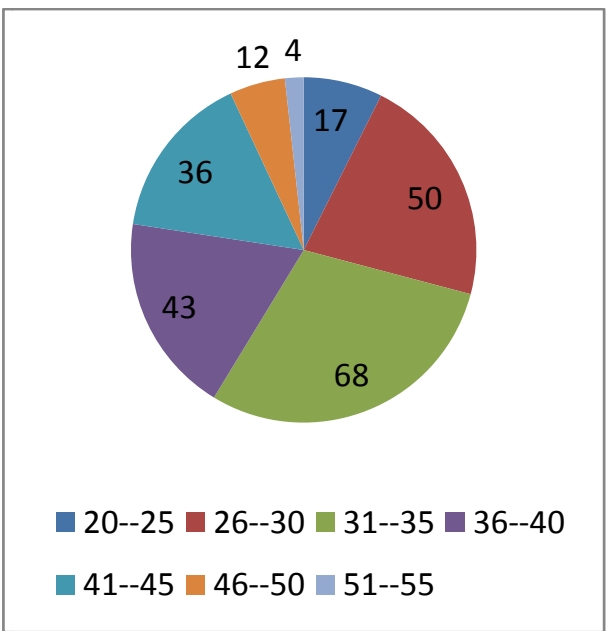

Age

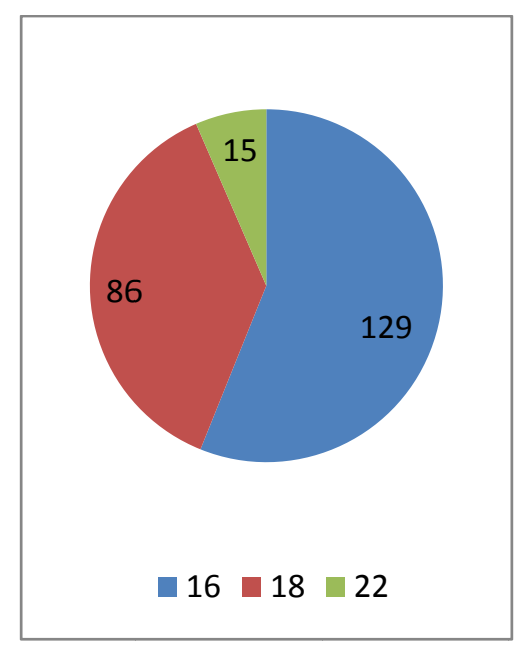

Years of education

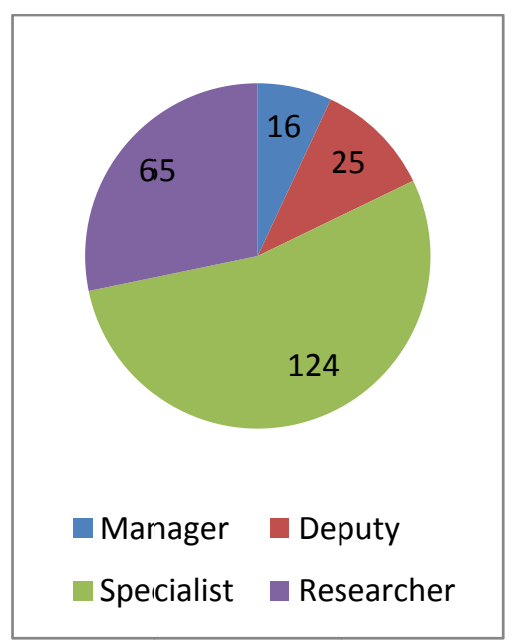

Job title

Fig. 2. Personal characteristics of the participants

According to the results of Fig. 2, most participants were middle aged, maintained some university education with some specialty.

\section{The results}

In this section, we present details of our findings on testing the effects of four factors including competitive condition, product development strategy, competitive advantage and economic growth on customers' intention to purchase using structural equation modeling technique. Fig. 2 shows details of our findings.

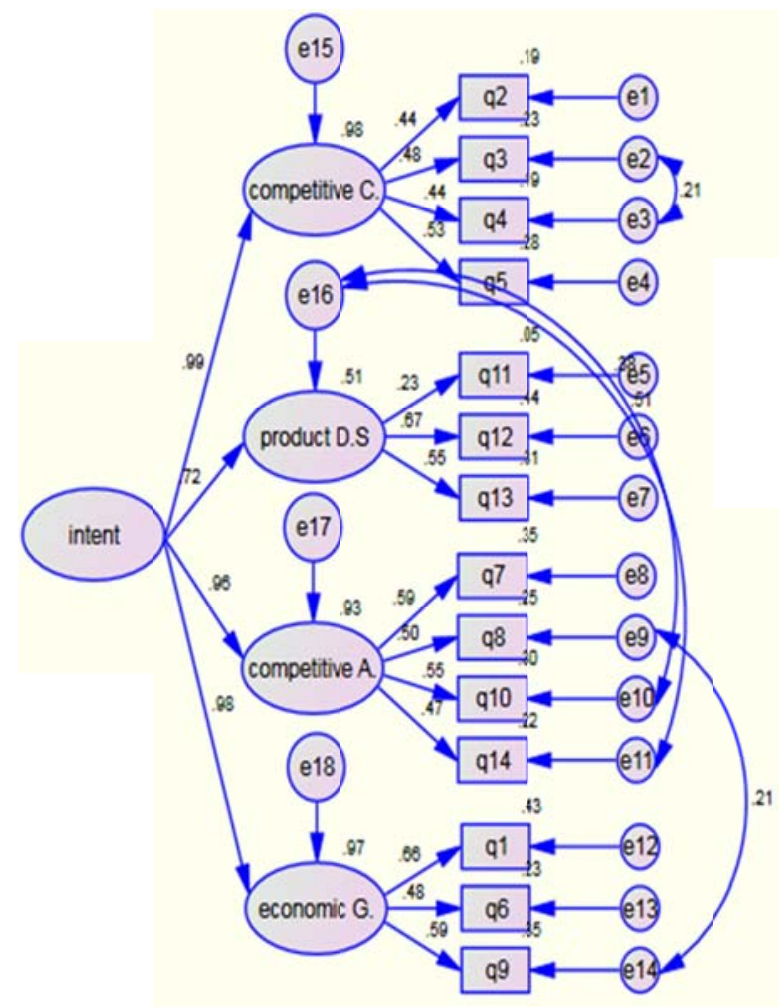

Fig. 2. The results of structural equation modeling

In our survey, all statistical observations such as GFI, RMSEA, etc. are within acceptable levels. Based on the results of Fig. 2, we may summarize our findings in Table 1 as follows, 
Table 1

The results of testing the effects of various factors on purchase intention

\begin{tabular}{lccl}
\hline Variable & Factor loading & P-Value & Result \\
\hline Competitive condition & 0.979 & 0.0001 & Confirmed \\
Product development strategy & 0.970 & 0.001 & Confirmed \\
Competitive advantage & 0.930 & 0.0001 & Confirmed \\
Economic growth & 0.512 & 0.008 & Confirmed \\
\hline
\end{tabular}

Based on the results of Table 2, all four items have positive and meaningful impacts on purchase intention.

\section{Conclusion}

In this paper, we have presented an empirical investigation to study the effects of different factors on purchase intention in auto industry. The study has designed a questionnaire and distributed it among some randomly selected people who owned Iranian cars in city of Tehran, Iran. Using structural equation modeling, the study has confirmed that competitive condition, product development strategy, competitive advantage and economic growth influence positively on customers' intention to purchase.

\section{Acknowledgement}

The authors would like to thank the anonymous referees for constructive comments on earlier version of this paper.

\section{References}

Ardichvili, A., Cardozo, R., \& Ray, S. (2003). A theory of entrepreneurial opportunity identification and development. Journal of Business Venturing, 18(1), 105-123.

Bagchi-Sen, S. (2007). Strategic considerations for innovation and commercialization in the US biotechnology sector. European Planning Studies,15(6), 753-766.

Bandarian, R. (2007). Evaluation of commercial potential of a new technology at the early stage of development with fuzzy logic. Journal of Technology Management \& Innovation, 2(4), 73-85.

Barney, J. (1991). Firm resources and sustained competitive advantage. Journal of Management, 17(1), 99-120.

Boehm, D. N., \& Hogan, T. (2013). Science-to-Business collaborations: A science-to-business marketing perspective on scientific knowledge commercialization. Industrial Marketing Management, 42(4), 564-579.

Boulay, D. A., Worley, C. T., \& Barnes, M. (2008). Engagement through information: supporting technology commercialization. Journal of Agricultural \& Food Information, 9(4), 310-316.

Dubin, R. (1978). Theory building (pp. 97-104). New York: Free Press.

Schmidt-Mohr, U., \& Villas-Boas, J. M. (2008). Competitive product lines with quality constraints. Quantitative Marketing and Economics, 6(1), 1-16. 